\title{
Tests for Seedborne Transmission of Zucchini Yellow Mosaic Virus
}

\author{
Richard W. Robinson', Rosario Provvidenti' ${ }^{2}$, and Joseph W. Shail ${ }^{1}$ \\ Cornell University, New York Agricultural Experiment Station, Geneva, NY 14456
}

Zucchini yellow mosaic virus (ZYMV) was first reported by Lisa et al. (1981) in Italy and by Lecoq et al. (1981) in France. It was found in Connecticut in 1982 (Provvidenti et al., 1983) and, subsequently, in many other parts of the United States (Provvidenti, 1986; Provvidenti et al., 1984a), including Hawaii (Ullman et al., 1991) and Guam (Yudin et al., 1990). ZYMV also has been found on cucurbits in Australia (Greber et al., 1987), Bangladesh (Akanda et al., 1991), Canada (Stobbs and van Schagan, 1990), Czechoslovakia (Chod and Jokes, 1991), Egypt (Provvidenti et al., 1984b), Germany (Lecoq et al., 1983), Guadaloupe (Quoit-Douine et al., 1986), Holland (Schrijnwerkers et al., 1991), Iran (Ghorbani, 1988), Israel (Lecoq et al., 1983), Japan (Ohtsu and Sake, 1985), Jordan (Al-Muss, 1989), Lebanon (Lesemann et al., 1983), Mauritius (Lisa and Lecoq, 1984), Mexico (Sanchez, 1990), Morocco (Lecoq et al., 1983), Saudi Arabia (Abdulsalam et al., 1988), Singapore (Wong and Lee, 1992), Spain (Luis-Arteaga, 1990), Syria (Katul and Makkouk, 1987), Taiwan (Huang et al., 1986), Turkey (Davis, 1986), the United Kingdom (Lisa and Lecoq, 1984), Venezuela (Hernandez et al., 1989), and Yemen (Alhubaishi et al., 1988). Its apparent rapid spread to so many distant countries on five continents and its erratic incidence suggests that ZYMV maybe seedborne. Seed transmission of this virus would have very serious implications for seed specialists, growers, and others, since this devastating disease has caused widespread losses (Provvidenti et al., 1984a). Several researchers have attempted to determine whether ZYMV can be transmitted via seed and to what extent. In this paper we review the work that we and others have done on this subject.

Seed transmission tests in Cucurbita species. There are conflicting reports for seed transmission of ZYMV in Cucurbita species. Nameth et al. (1985) tested 1400 seed from several squash cultivars (C. pepo L.) infected with ZYMV. Although enzyme-linked immunosorbent assays (ELISA) confirmed that parent plants were infected with this virus, all their progenies were found to be free of ZYMV.

Conversely, Davis and Mizuki (1986a, 1986b), working with progenies of ZYMVinfected C. pepo 'Black Beauty' plants, reported that 246 of 1298 seedlings were in-

\footnotetext{
Received for publication 26 Mar. 1992. Accepted for publication 22 Apr. 1993. The cost of publishing this paper was defrayed in part by the payment of page charges. Under postal regulations, this paper therefore must be hereby marked advertisement solely to indicate this fact.

'Dept. of Horticultural Sciences.

${ }^{2}$ Dept. of Plant Pathology.
}

fected with a virus that was serologically related to ZYMV. The average seed transmission rate was $18.9 \%$, but it ranged from 0 to $80.7 \%$ when based on individual infected fruits. However, this seedborne virus caused very mild and often inconspicuous symptoms that were mostly confined to the lower leaves. Since these symptoms were radically different from those displayed by the ZYMV-infected parent plants, the true identity of this seedborne virus is uncertain.

Greber et al. (1987) reported a lack of seed transmission in 1000 C. maxima Duch. ex Lam. plants grown from seeds of ZYMVinfected plants. The following year, however, Greber et al. (1988) demonstrated that one of 100 plants derived from seed of infected $C$. pepo fruits developed symptoms incited by ZYMV.

More recent reports are also contradictory. Gleason and Provvidenti (1990) tested seeds from 30 pumpkin (C. pepo) fruit infected with ZYMV. The seeds were germinated in a greenhouse maintained under strict sanitary conditions. Three of the 6800 resulting plants were infected with squash mosaic virus (SqMV), but none with ZYMV. Attempts by Visser (cited by Schrijnwerkers et al., 1991) to demonstrate seed transmission of ZYMV in 13,000 plants grown from commercial seedlots of $C$. pepo also were negative.

Conversely, Schrijnwerkers et al. (1991) reported that two of $648 C$. pepo cv. Black Beauty seedlings $(0.3 \%)$ were infected by ZYMV via seeds, but none of the 3548 seedlings of other cultivars developed viral symptoms. Using electron microscopy, these workers found ZYMV particles on the seedcoat, but not in the embryo.

We obtained mostly negative results in a series of tests conducted during the last 7 years. Provvidenti and Robinson (1987) grew 4266 summer squash plants (C. pepo) from seed produced commercially in a field where the majority of the plants were infected with ZYMV. None of these plants grown in the field in 1985 had ZYMV symptoms, but infections caused by cucumber mosaic virus (CMV), watermelon mosaic virus (WMV), and clover yellow vein virus (CYVV) were found. In the following year, 2475 progeny of ZYMV-infected $C$. pepo 'Ambassador' plants tested in the field were also free of ZYMV.

In 1989, 41 of 4772 field-grown summer squash plants, also derived from seed of ZYMV-infected plants, developed leaf mottling and other abnormalities at the seedling stage. ELISA tests with a monoclinal antiserum of ZYMV revealed that four of these plants, each from a different breeding line, were infected with ZYMV. The virus titre was high in two of these plants. Viral infection probably occurred in an early stage of plant development, since the first leaves displayed prominent symptoms. The remaining 37 plants were free of ZYMV infection. One was a chlorophyll-deficient mutant and the rest were infected with CMV or WMV.

One of 35 volunteer $C$. pepo plants in 1989 , in a field where $C$. pepo was inoculated with the Connecticut strain of ZYMV the previous year, exhibited symptoms typical of ZYMVCT. Serological tests confirmed the presence of this strain in the volunteer plant. Progenies of this plant, as well as those of the four other plants found to have ZYMV in 1989, were tested in the greenhouse the following winter, but the resulting 389 plants were free of any viral infection.

Progenies of 72 breeding lines and cultivars of $C$. pepo that were infected with ZYMV in the field the previous year were also evaluated for seed transmission under greenhouse conditions in Winter 1990. Two plants developed leaf mottling and enation, but the causal agent was identified by ELISA tests as SqMV, which is known to be seedborne (Kendrick, 1934; Rader et al., 1947). The remaining 7594 plants were negative for ZYMV infection. This total included 279 seedlings grown from seed immersed for $15 \mathrm{~min}$ in an extract of ZYMV-infected fruit. Twenty-four of these seeds had longitudinal cracks along the margin, which allowed the virus extract to penetrate the seedcoat, but none of the plants grown from this seed developed symptoms of ZYMV or any other virus.

During Winter 1991, more seeds from severely infected plants were tested in a greenhouse free of any viral sources. None of $423 C$. moschata (Duch. ex Lam.) Duch. ex Poir., 506 C. maxima, and 2903 C. pepo plants developed symptoms of viral infection. The C. pepo population included 334 'Black Beauty' plants-a cultivar reported to transmit ZYMV via its seed (Davis and Mizuki 1986a; Schrijnwerkers et al., 199 1)—but all plants remained symptomless.

Seed transmission tests in Cucumis species. Neither 1009 melon plants (Lecoq et al., 198 1) nor $\approx 200$ 'Honey Dew' seedlings (Greber et al., 1988) developed symptoms caused by ZYMV, even though the plants were progenies of ZYMV-infected $C$. melo L. plants. Our 1986 tests used seed harvested in 1985 from ZYMV-infected 'Iroquois' melons. None of the 100 resulting plants were infected by this virus during 2 months in an insect-free greenhouse. ELISA tests confirmed that each plant was free of ZYMV infection. Similarly, none of 334 plants grown in the field in 1986 from the same seedlot developed symptoms that could be attributed to ZYMV infection. Thus, we have no evidence to indicate that 
ZYMV is transmitted by seed in C. melo. However, these populations were much smaller than those investigated for Cucurbita species. Consequently, a low rate of viral transmission in melon seed cannot be ruled out.

Seed was harvested from seven populations of cucumber (Cucumis sativus L.) and planted in an insect-free greenhouse in 1992. Each of the inoculated parental plants displayed prominent symptoms of ZYMV, but all 11,475 progeny were symptomless.

Seed transmission tests in other plant species. A virus maybe seedborne in one species but not in another. Seed transmission of ZYMV in other species might contribute to the spread of this virus to squash and melon plantings. Besides some members of at least 16 other plant families, ZYMV also is known to infect at least 26 cucurbit species that we did not test for seed transmission (Lecoq et al., 1981; Lisa et al., 1981). Al-Muss (1989) reported that ZYMV is seedborne in Ranunculus sardous Crantz-two of 150 plants were infected with ZYMV when grown in insect-proof cages.

Genetic variation in the host for seed transmission. There may be genetic variation in the host for seed transmission of a virus, so that it can be seedborne in some genotypes of a species but not in others. We obtained no evidence, however, for a high rate of seed transmission of ZYMV in any $C$. pepo genotype. Schrijnwerkers et al. (1991) and Davis and Mizuki (1986a, 1986b) reported seedborne ZYMV in C. pepo cv. Black Beauty, but we were not able to confirm that this cultivar is particularly prone to seed infection. In addition, in 1990 and 1991 we tested progeny of 119 other cultivars and breeding lines of $C$. pepo in an aphid-free greenhouse and found no evidence for genetic variation in seed transmission of the virus. Nor did we find evidence of a high genetic seed transmission rate in five C. pepo plants naturally infected with ZYMV in 1989, since their progeny tests were negative.

Seed treatment. Schrijnwerkers et al. (1991) demonstrated by election microscopy that seed of ZYMV-infected squash fruit are coated with the virus externally. Since we manually cleaned and dried the seed in our tests, we expected that many external contaminants, including some virus particles, were removed. However, immersing seed in extracts of ZYMV-inoculated plants and planting this seed without washing or drying did not promote seed transmission of ZYMV. The seed and extracts were from fruit that were misshapened and partly or entirely green, even for breeding lines that normally have yellow fruit, which indicates that these fruit were severely affected by ZYMV. The seed from these fruit did not transmit the virus even when they were coated with fruit particles and juice at the time of planting.

ZYMV variability. Lisa and Lecoq (1984) described ZYMV as being remarkably variable. Various strains of ZYMV, differing in symptoms and geographical distribution, are known (Al-Musa, 1989; Davis and Mizuki, 1987; Lecoq and Pitrat, 1984; Lecoq et al., 1981; Lesemann et al., 1983; Provvidenti et al., 1984a). Various pathotypes of ZYMV, distinguished by their effect on resistant genotypes, have also been reported (Greber et al., 1988; Lecoq and Pitrat, 1984; Lecoq et al., 1981). Variants of the virus that differ in aphid transmissibility are also known (Lecoq, 1986). To our knowledge, however, no evidence exists showing that these variable forms of ZYMV differ in seed transmission. Our greenhouse tests using the Connecticut and Florida strains of ZYMV gave no indication of genetic variation in the virus for seed transmission rate, since infected squash plants did not transmit either virus strain through their seed.

The multiple ZYMV strains and pathotypes suggest that the virus may have been present considerably longer than the past decade, when the disease was recognized. The different strains and pathotypes of ZYMV do not appear to be the result of extreme instability of a recently originated virus. Lecoq and Pitrat (1984) reported that ZYMV variants were stable after passing through various hosts. R. Provvidenti (unpublished data) did not observe any instability in the Connecticut or Florida ZYMV strains in the ten years that they were maintained and used in resistance tests.

Conclusions. We did not obtain unequivocal evidence for seed transmission of ZYMV in our tests with squash, cucumber, and melon. Results of our tests and those reported in the literature are summarized in Table 1. The seed company that provided squash seed for our 1985 test informed us that their seed production field was severely infected with ZYMV, but the precise proportion of infected plants was not determined. ZYMV infection of seed parents was $100 \%$ for all other tests. If we exclude the results of our 1985 tests because of the uncertain infection rate, we grew a total of 7282 plants in 1986 and 1989 in the field from seed of ZYMV-infected C. pepo. Five plants were infected with $\mathrm{ZYMV}$, a maximum seed transmission rate of $\approx 0.07 \%$. This is significantly less than the $18.9 \%$ rate reported by Davis and Mizuki (1986a, 1986b), but similar to the $0.047 \%$ seed transmission rate reported by Schrijnwerkers et al. (1991). Virus transmission could be due entirely to insects, not seed, since the plants were grown in the field and were subject to natural infection.

ZYMV was not transmitted via seed to Cucurbita and Cucumis plants in tests made in a greenhouse in midwinter, when virus transmission by aphids from an external source was prevented by the extremely low outdoor temperature. It is unlikely $(P<0.01)$ that seed transmission of ZYMV at a very low frequency, comparable to the $0.07 \%$ rate suggested by our field test results, would have occurred without being detected in the greenhouse population of 10,888 plants.

It is difficult to prove with certainty that a highly contagious virus is seed-transmitted at a very low frequency if there is also a possibility of natural infection, and even greenhouse tests at another time of the year than that of our tests, or in an area with milder winter weather, might not eliminate the possibility of virus infection by aphids or another source. Seed transmission of zucchini yellow mosaic virus, if it does occur, is evidently a rare event in the cucurbit hosts we investigated.

\section{Literature Cited}

Abdulsalam, K.S., M.F.A. Ghadir, and E.A. Salama. 1988. Ability of certain aphid species to transmit zucchini yellow mosaic virus (ZYMV). Assiut J. Agr. Sci. 19:271-279.

Akanda, A.M., K. Tsuno, and S. Wakimoto. 1991. Serological detection of four plant viruses in cucurbitaceous crops from Bangladesh. Ann. Phytol. Soc. Jpn. 57:499-505.

Alhubaishi, A.A., D.G.A. Walker, M.J.W. Webb, C.J. Bolland, and A.A. Cook. 1988. A survey of horticultural plant virus diseases in the Yemen Arab Republic. Food and Agr. Organization Plant Protection Bul. 35: 135-143.

Al-Musa, A.M. 1989. Severe mosaic caused by zucchini yellow mosaic virus in cucurbits from Jordan. Plant Pathol. 38:541-546.

Chod, J. and M. Jokes. 1991. The occurrence of the zucchini yellow mosaic virus in Czechoslovakia. Sbornik Uvtiz Ochrana Rostlin 27:111115.

Davis, R.F. 1986. Partial characterization of zucchini yellow mosaic virus isolated from squash in Turkey. Plant Dis. 70:735-738.

Davis, R.F. and M.K. Mizuki. 1986a. Seed transmission of zucchini yellow mosaic virus (ZYMV) in Cucurbita pepo. Proc. Workshop Epidemiol.

Table 1. Host, population size tested, and incidence of virus in progeny of zucchini yellow mosaic virusinfected plants

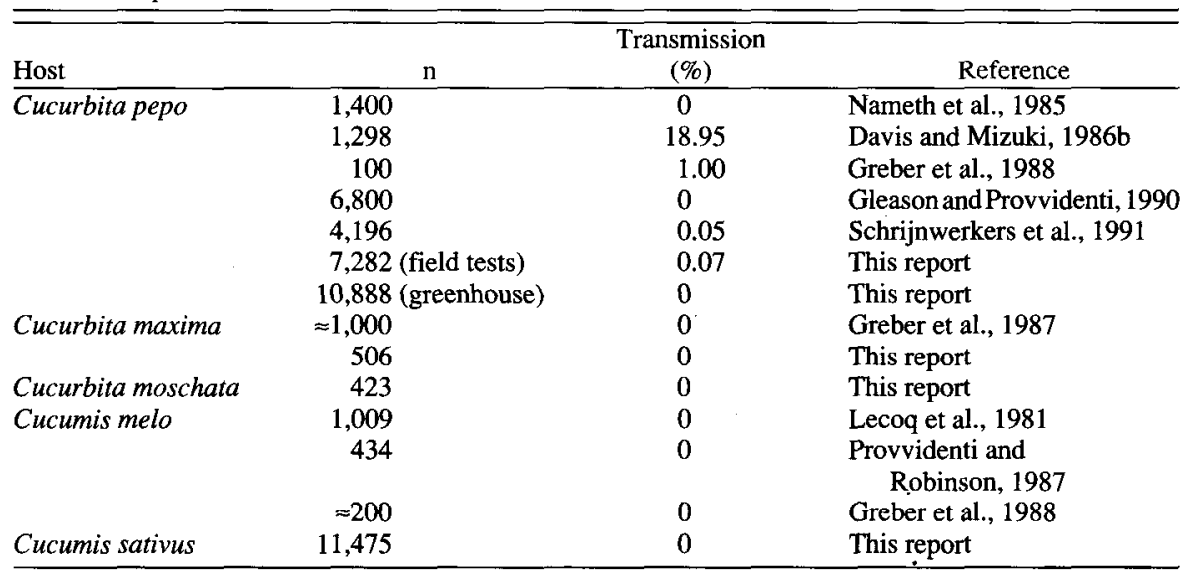


Plant Virus Dis., Orlando, Fla. 2:6-8

Davis, R.F. and M.K. Mizuki. 1986b. Seed transmission of zucchini yellow mosaic virus in squash. Phytopathology 76:1076.

Davis, R.F. and M.K. Mizuki. 1987. Detection of cucurbit viruses in New Jersey. Plant Dis. 71:4044.

Ghorbani, S. 1988. Isolation of zucchini yellow mosaic virus in the Tehran Province. Iranian J. Plant Pathol. 24:13-15.

Gleason, M.L. and R. Provvidenti. 1990. Absence of transmission of zucchini yellow mosaic virus from seeds of pumpkin. Plant Dis. 74:828.

Greber, R.S., G.D. McLean, and M.S. Grice. 1987. Zucchini yellow mosaic virus in three states of Australia. Austral. Plant Pathol. 16:19-21.

Greber, R.S., D.M. Persley, and M.E. Herrington. 1988. Some characteristics of Australian isolates of zucchini yellow mosaic virus. Austral. J. Agr. Res. 39:1085-1094.

Hernandez, J., G.E. Trujillo, M. Albarracin, F. Zapata, and J. Hernandez. 1989. Nueva enfermedad viral afectando cucurbitaceas en Venezuela. Fitopat. Venezolana 2:23.

Huang, C.H., S.H. Hsen, and Y.J. Chao. 1986. purification and serology of an isolate of zucchini yellow, mosaic virus. J. Agr. Res. China 35:495-503.

Katul, L. and K.M. Makkouk. 1987. Occurrence and serological relatedness of five cucurbit potyviruses in Lebanon and Syria. Phytopathol. Medit. 26:36-42.

Kendrick, J.B. 1934. Cucurbit mosaic transmitted by muskmelon seed. Phytopathology $24: 820-$ 823

Lecoq, H. 1986. Poorly aphid transmissible variant of zucchini yellow mosaic virus. Phytopathology $76: 1083$.

Lecoq, H., V. Lisa, and G. Dellavalle. 1983. Serological identity of muskmelon yellow stunt and zucchini yellow mosaic viruses. Plant Dis. 67:824-825

Lecoq, H. and M. Pitrat. 1984. Strains of zucchini yellow mosaic virus in muskmelon (Cucumis melo L.). Phytopathol. Z. 111:165-173.

Lecoq, H., M. Pitrat, and M. Clément. 1981. Identification et caractérisation d'un potyvirus provoquant la maladie du rabougrissement du melon. Agronomic 1:827-834.

Lesemann, D.E., K.M. Makkouk, and R. Koenig. 1983. Natural infection of cucumbers by zucchini yellow mosaic virus in Lebanon (Cucumis sativus). Phytopathol. Z. 108:304-323.

Lisa, V., G. Boccardo, G. D’Agostino, G. Dellavalle, and M. d'Aquilio. 1981. Characterization of a potyvirus that causes zucchini yellow mosaic. Phytopathology 71:667-672.

Lisa, V. and H. Lecoq. 1984. Zucchini yellow mosaic virus. Commonwealth Agr. Bur./Assn. Appl. Biol. Descriptions Plant Viruses 282.

Luis-Arteaga, M. 1990. Detection of zucchini yellow mosaic virus on cucurbit crops in Spain (in Spanish). Investigation Agraria Production y Protection Vegetales 5:167-177.

Nameth, S.E., J.A. Dodds, and A.O. Paulus. 1985 Zucchini yellow mosaic virus associated with several diseases of melon and watermelon in southern California desert valleys. Plant Dis. 69:785-788

Ohtsu, Y. and N. Sake. 1985. Zucchini yellow mosaic virus isolated from pumpkin in Milyako and Yaeyama Islands, Okinawa, Japan. Ann. Phytopathol. Soc. Jpn. 51:234-237.

Provvidenti, R. 1986. Occurrence of zucchini yellow mosaic virus in the United States in 1985. Cucurbit Genet. Coop. Rpt. 9:96.

Provvidenti, R., D. Gonsalves, and H.S. Humaydan. 1983. The occurrence of zucchini yellow mosaic virus in the United States. Cucurbit Genet. Coop. Rpt. 6:99.
Provvidenti, R., D. Gonsalves, and H.S. Humaydan. 1984a. Occurrence of zucchini yellow mosaic virus in cucurbits from Connecticut, New York, Florida, and California. Plant Dis. 68:443-446.

Provvidenti, R., H.M. Munger, and M.O. Paulus. 1984b. Epidemics of zucchini yellow mosaic virus in Egypt in the spring of 1983. Cucurbit Genet. Coop. Rpt. 7:78-79.

Provvidenti, R. and R.W. Robinson. 1987. Lack of seed transmission in squash and melon plants infected with zucchini yellow mosaic virus. Cucurbit Genet. Coop. Rpt. 10:81-82.

Quoit-Douine, L., J.B. Quoit, and G. Labonne. 1986. Description préliminaire d'un potyvirus isolé de courgette (Cucurbita pepo L.) en Guadaloupe. Agronomie 6:227-234.

Rader, W.E., H.F. Fitzpatrick, and E.M. Hildebrand. 1947. A seed-borne virus of muskmelon. Phytopathology 37:809-816.

Sanchez, F.D. 1990. Enfermedades complejo causadas por virus fitopatogenos. Revista Mexicana Fitopatologia 8:99-101.

Schrijnwerkers, C.C.F.M., N. Huijberts, and L. Bos. 1991. Zucchini yellow mosaic virus: Two outbreaks in the Netherlands and seed transmissibility. Neth. J. Plant Pathol. 97:1-7.

Stobbs, L.W. and J.G. van Schagen. 1990. First report of zucchini yellow mosaic virus in Ontario. Plant Dis. 74:394

Ullman, D.E., J.J. Cho, and T.L. German. 1991 Occurrence and distribution of cucurbit viruses in the Hawaiian Islands. Plant Dis. 75:367-370.

Wong, S.M. and S.C. Lee. 1992. First report of zucchini yellow mosaic virus in Singapore. Plant Dis. 76:972

Yudin, L.S., G.C. Wall, R.J. Quitugua, M.W. Johnson, and J. Cho. 1990. Identification of virus diseases of cucurbits on Guam. Phytopathology 80:1063.

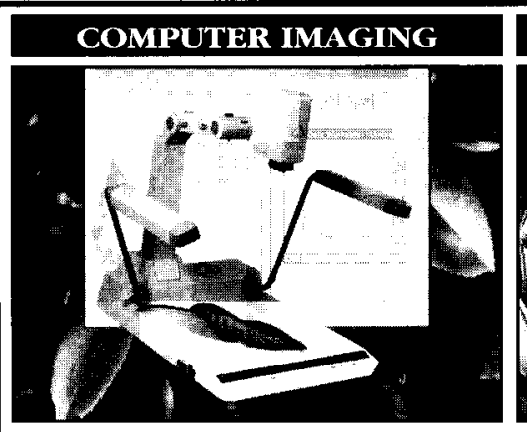

Cl-205 color IMAcING ANALYsIs sYsteM

What makes the Computer Imaging Analysis Software (CLAS) for Windows 3.1 so powerful?

Integrated color and monochrome image processing and powerful measurement menu for a variety of applications to include analysis of diseased area/insect damage, object count, root length measurement, and much more

Data automatically assigns to built-in data worksheet that has over 50 mathematical functions

- Four layer multi-color overlay to compare, annotate, and analyze images

- Capture image from your choice of high resolution cameras based upon application

Q Save or print data, plots, and images, or simply export files to : thother program

Call Now for your free Informatton package!

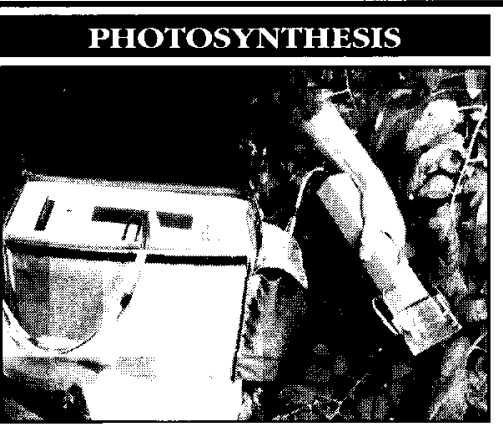

\section{CI-301PS PORTABLE} Photosynthesis SYSTEN

Interchangeable chamber head for different types of leaves

Open or closed system of photosynthesis measurement

- Measures photosynthesis, transpiration stomatal resistance, internal $\mathrm{CO}_{2}$, and $\mathrm{CO}_{2}$ in absolute, differential, and two-channel mode

- Plots photosynthesis curve on display

- Microprocessor controlled system with memory card for data storage

- Controlled cooling system and light attachment available

- Adjustable humidity and $\mathrm{CO}_{2}$ control unit with pure $\mathrm{CO}_{2}$ source available

Infrared non-contact leaf temperature measurement

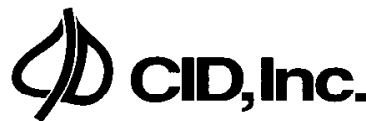

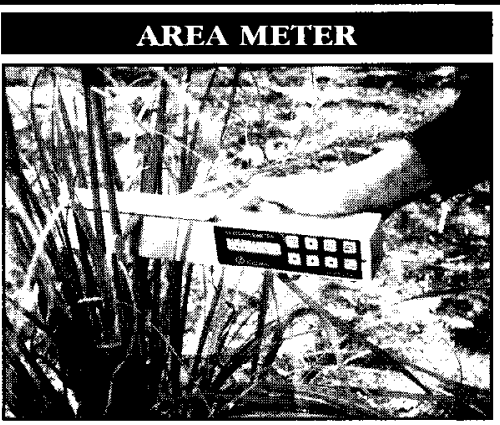

CI-203 PORTABLE LASER

\section{AREA METER}

- Resolution $0.1 \mathrm{~mm}$

- Non-destructive measurement

Measures area, length, width, perimeter, shape-factor, ratio

- Built-in data logger with RS232C interface

Width $15.4 \mathrm{~cm}$ and length practically unlimited

\section{Cl-203ca PonTanie}

CONVEYAR ATACHMENT

attaches to CI-203 for

continuous leaf feeding

Measuring width $25.4 \mathrm{~cm}$

- Conveyer speed $10 \mathrm{~cm} / \mathrm{second}$

4018 N.E. 112th Avenue,

Suite D-8

Vancouver, WA 98682 U.S.A

Phone (206) 254-7874

Fax (206) 254-7923

Toll Free ( 800$) 767-0119$ 